\title{
KONSEP SAKINAH, MAWADDAH DAN RAHMAH DALAM PERNIKAHAN
}

\author{
Henderi Kusmidi*
}

Abstrak

Perkawinan merupakan bagian dari ajaran Islam. Siapa yang menghindari perkawinan berarti ia telah meninggalkan sebagian dari ajaran agamanya. Disamping itu perkawinan dapat menghindarkan diri dari perbuatan zina. Islam melarang ummatnya melepaskan naluri seksual secara bebas tidak terkendali. Karena itulah Islam mengharamkan perbuatan zina dengan segala hal yang mengantarkannya dan segala sesuatu yang berhubungan dengannya. Pada saat yang sama Islam memerangi kecenderungan sebaliknya yaitu kecenderungan yang melawan naluri dan mengekangnya. Karena itulah ia menyerukan kepada perkawinan, melarang kecenderungan melajang terus dan mengebiri diri. Tidak halal bagi seorang muslim berpaling dari perkawinan, pada hal ia mampu melakukannya dengan alasan konsentrasi untuk beribadah, menjauhi dari dunia dan mengabdi secara penuh kepada Allah SWT.

Kata Kunci : Perkawinan, Sakinah, Mawaddah, Rahmah dan Hukum Islam

\section{Pendahuluan}

Islam mendorong untuk membentuk keluarga, Islam mengajak manusia untuk hidup dalam naungan keluarga karena keluarga seperti gambaran kecil dalam kehidupan stabil yang menjadi pemenuhan keinginan manusia tanpa menghilangkan kebutuhannya. Keluarga merupakan tempat fitrah yang sesuai dengan keinginan Allah SWT bagi kehidupan manusia sejak keberadaan khalifah. ${ }^{1} \quad$ Sesungguhnya pernikahan tidak hanya bertujuan untuk memenuhi insting dan berbagai keinginan yang bersifat materi. Lebih dari itu terdapat berbagai tugas yang harus dipenuhi baik dari segi kejiwaan, ruhaniyah, kemasyarakatan harus menjadi tanggungjawabnya. Kepuasan insting sungguh bisa tercukupi dengan kecantikan dan keindahan, namun tidak dapat mencukupi dalam pemuasan kerinduan ruh dan keinginan jiwa seperti ketenangan, cinta dan keamanan. ${ }^{2}$

Dalam pandangan Islam perkawinan bukanlah urusan perdata semata, bukan pula urusan keluarga dan masalah budaya, tetapi juga terkait dengan masalah agama karena perkawinan itu dilakukan untuk memenuhi dan menaati aturan Allah SWT 
dan sunnah nabi Muhammad SAW serta dilaksanakan sesuai dengan petunjuk Allah dan Rasul Nya. Pekawinan dilakukan oleh dua insan yang berbeda jenis kelamin, kultur dan watak yang berjanji dan bersedia mematuhi janji yang telah diucapkan sebagai makhluk sosial. Secara otomatis juga mempunyai nilai kontrak sosial antara laki-laki dan perempuan yang sifatnya manusiawi.

Kecenderungan manusia untuk berkeluarga merupakan naluri yang diwariskan secara genitika agar kelangsungan generasi spesies manusia tetap terjaga. Syari'at Islam telah mengatur kecenderungan naluri itu agar tidak liar, brutal dan tak bermatabat melalui lembaga pernikahan. Pernikahan yang sah menurut Syari'at Islam merupakan awal dari pembentukan keluarga sakinah sepanjang suami isteri menjalankan hak dan kewajibannya masing-masing.

$$
\text { Kita sering mendengar }
$$
istilah sakinah, mawaddah, warahmah. Kata-kata ini begitu populer terlebih lagi ketika kerabat ataupun kenalan kita hendak melaksanakan sebuah hajat pernikahan. Siapapun orangnya ketika menginjak dunia rumah tangga pasti menginginkan kehidupan yang sakinah, mawaddah,

warahmah. Kata-kata ini begitu mudah untuk diucapkan, namun dalam kenyataannya untuk membentuk sebuah keluarga yang sakinah, mawaddah, warahmah, memang tidak semudah membalikkan telapak tangan. Membutuhkan sinkronisasi antara niat, pemahaman dan perbuatan. Dalam upaya memahami konsep sakinah, mawaddah, warahmah dalam perkawinan, maka penulis mencoba memaparkan beberapa definisi tentang sakinah, mawaddah, warahmah dan aplikasinya dalam kehidupan berumah tangga.

\section{A. Dasar Hukum Perkawinan}

Penghargaan Islam terhadap ikatan pernikahan besar sekali, Allah menyebutkan sebagai ikatan yang kuat, sebagaimana Allah SWT berfirman :

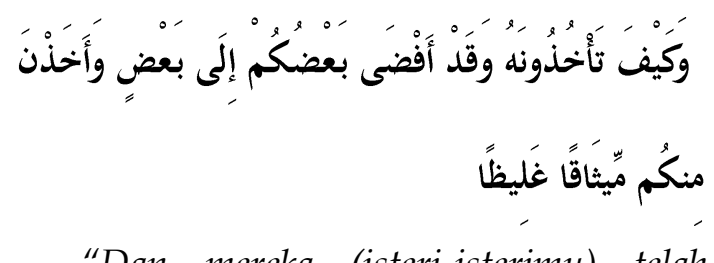
mengambil dari kamu perjanjian yang kuat".(An Nisaa: 21). ${ }^{3}$

Sampai-sampai ikatan perkawinan itu ditetapkan sebanding dengan separuh agama. Rasulullah Shallallahu 'alaihi wa sallam telah bersabda:

"Barangsiapa menikah, maka ia telah melengkapi separuh dari agamanya. Dan 
hendaklah ia bertaqwa kepada Allah dalam memelihara yang separuhnya lagi". ${ }^{4}$

Islam Tidak Menyukai Membujang, Rasulullah Shallallahu 'alaihi wa sallam memerintahkan untuk menikah dan melarang keras kepada orang yang tidak mau menikah. Anas bin Malik rahimahullah berkata : "Rasulullah Shallallahu 'alaihi wa sallam memerintahkan kami untuk menikah dan melarang kami membujang dengan larangan yang keras." Beliau Shallallahu 'alaihi wa sallam bersabda :

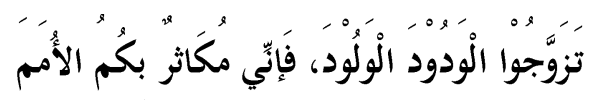

"Nikahilah wanita yang subur dan penyayang. Karena aku akan berbanggga dengan banyaknya umatku di hadapan umatumat" $^{\prime \prime}$

Pernah suatu ketika, tiga orang sahabat datang bertanya kepada isteriisteri Nabi Shallallahu 'alaihi wa sallam tentang peribadahan Beliau Shallallahu 'alaihi wa sallam. Kemudian setelah diterangkan, masing-masing ingin meningkatkan ibadah mereka. Salah seorang dari mereka berkata: “Adapun saya, akan puasa sepanjang masa tanpa putus". Sahabat yang lain berkata: “Adapun saya akan menjauhi wanita, saya tidak akan nikah selamanya ". Ketika hal itu didengar oleh Nabi SAW, Beliau keluar seraya bersabda :
"Benarkah kalian telah berkata begini dan begitu? Sungguh demi Allah, sesungguhnya akulah yang paling takut dan taqwa kepada Allah diantara kalian, akan tetapi aku berpuasa dan aku berbuka, aku shalat dan aku juga tidur dan aku juga menikahi wanita. Maka barangsiapa yang tidak menyukai sunnahku, maka ia tidak termasuk golonganku".

Allah memerintahkan untuk menikah. Dan seandainya mereka fakir, niscaya Allah SWT akan membantu dengan memberikan rezeki kepada mereka. Allah SWT menjanjikan suatu pertolongan kepada orang yang menikah dalam firman-Nya QS. An Nur 32-34 :

Dan nikahkanlah orang-orang yang masih membujang di antara kamu, dan juga orang-orang yang layak (menikah) dari hamba-hamba sahayamu yang laki-laki dan perempuan. Jika mereka miskin, Allah akan memberikan kemampuan kepada mereka dengan karunia-Nya. Dan Allah Mahaluas (pemberian-Nya) lagi Maha Mengetahui. Dan orang-orang yang tidak mampu menikah hendaklah menjaga kesucian (diri)nya, sampai Allah memberi kemampuan kepada mereka dengan karunia-Nya. Dan jika hamba sahaya yang kamu miliki menginginkan perjanjian (kebebasan), hendaklah kamu buat perjanjian kepada mereka, jika kamu mengetahui ada kebaikan pada mereka, dan berikanlah kepada mereka sebagian dari harta Allah yang dikaruniakan-Nya kepadamu. Dan janganlah kamu paksa hamba sahaya perempuanmu untuk melakukan pelacuran, sedang mereka sendiri menginginkan kesucian, karena kamu hendak mencari keuntungan kehidupan duniawi. Barang siapa memaksa mereka, maka sungguh, Allah Maha Pengampun lagi Maha 
Penyayang (kepada mereka) setelah mereka dipaksa. Dan sungguh, Kami telah menurunkan kepada kamu ayat-ayat yang memberi penjelasan, dan contoh-contoh dari orang-orang yang terdahulu sebelum kamu dan sebagai nasehat bagi orang-orang yang bertakwa. "Dan nikahkanlah orang-orang yang sendirian diantara kamu dan orangorang yang layak (bernikah) dari hambahamba sahayamu yang laki-laki dan wanita. Jika mereka miskin, Allah akan memampukan mereka dengan karuniaNya. Dan Allah Maha Luas (pemberianNya) lagi Maha Mengetahui". (An Nur : 32-34)

Dalam pandangan Al-Qur'an salah satu tujuan pernikahan adalah untuk menciptakan sakinah, mawaddah dan rahmah antara suami, isteri dan anakanaknya. ${ }^{6}$ Hal ini ditegaskan oleh Allah SWT dalam surat Ar-Rum ayat 21 :

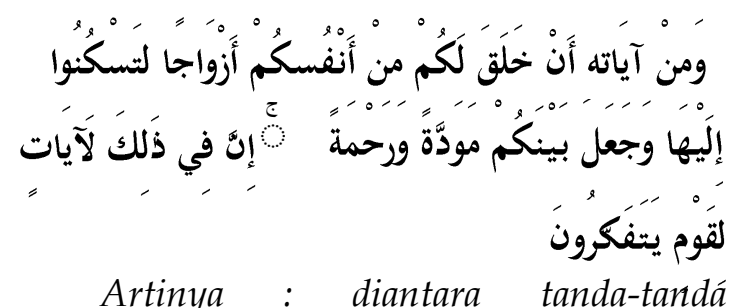
kekuasaan Nya adalah dia menciptakan untukmu isteri-isteri dari jenismu sendiri, supaya kamu cenderung dan merasa tenteram kepadanya, dan dijadikan-Nya diantaramu rasa kasih dan sayang. Sesungguhnya pada yang demikian itu benar-benar terdapat tandatanda bagi kaum yang berpikir. ${ }^{7}$

Adapun dasar hukum nikah dari alQur'an dalam surat An-Nahl Ayat 72 :

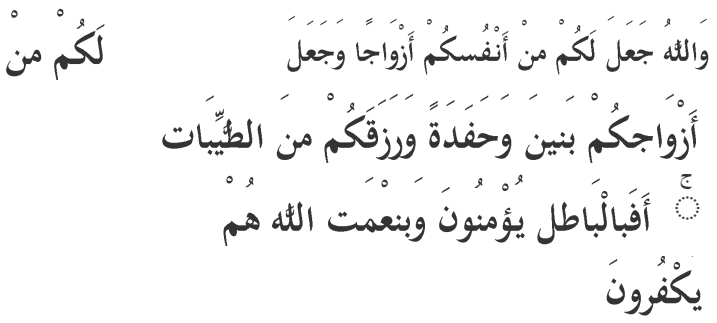

"Allah menjadikan bagi kamu isteriisteri dari jenis kamu sendiri dan menjadikan bagimu dari isteri-isteri kamu itu, anak-anak dan сиси-сисu, dan memberimu rezeki dari yang baik-baik. Maka mengapakah mereka beriman kepada yang bathil dan mengingkari nikmat Allah?"8

\section{B. Hukum Perkawinan}

Dasar hukum perkawinan yaitu hukum yang mengatur hubungan antara manusia dengan sesamnya yang menyangkut penyaluran kebutuhan biologis antar jenis, hak dan kewajiban yang berhubungan dengan akibat perkawinan. ${ }^{9}$ Perkawinan merupakan sunatullah pada dasarnya adalh mubah tergantung kepada tingkat maslahatnya. Imam Izzudin Abdussalam membagi maslahat menjadi tiga bagian yaitu :

1. Maslahat yang diwajibkan Allah bagi hamba-Nya. Maslahat wajib bertingkattingkat terbagi kepada faadhil (utama), afdhal (paling utama) dan mutawassith (tengah-tengah). Maslahat yang paling utama adalah maslahat yang pada dirinya terkandung kemuliaan, dapat menghilangkan mafsadah paling buruk dan dapat mendatangkan kemaslahatan yang paling besar, kemaslahatan jenis ini wajib dikerjakan.

2. Maslahat yang disunnahkan oleh syari' kepada hamba-Nya demi untuk kebaikannya, tingkat maslahat paling tinggi berada sedikit dibawah tingkat 
maslahat wajib paling rendah. Dalam tingkatan ke bawah maslahat sunnah akan sampai pada tingkat maslahat yang ringan yang mendekatkan maslahat mubah.

3. Maslahat mubah, bahwa dalam perkara mubah tidak terlepas dari kandungan nilai maslahat atau penolakan terhadap mafsadah. Imam izzudin berkata : sebagian diantaranya lebih bermanfaat dan lebih besar kemaslahatannya dari sebagian yang lain. Maslahat mubah ini tidak berpahala.

Perkawinan adalah suatu perbuatan yang disuruh oleh Allah dan Rasul-Nya. Banyak suruhan-suruhan Allah dalam AlQur'an untuk melaksanakan perkawinan. ${ }^{10}$ Diantaranya firman Allah SWT dalam surat An-Nuur ayat 32 :

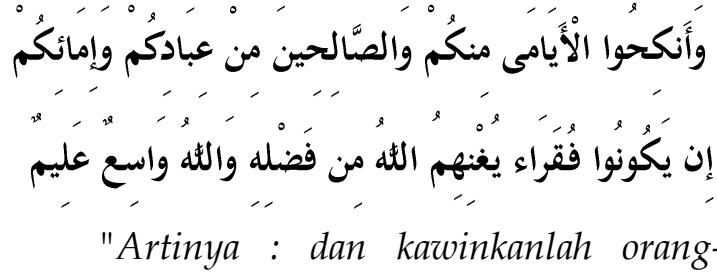
orang yang sendirian diantara kamu dan orang-orang yang layak untuk kawin di antara hamba-hamba sahayamu yang laki-laki dan hamba-hamba sahayamu yang perempuan. Jika mereka miskin Allah akan memberikan kemampuan kepada mereka dengan kurniaNya". 11

Begitu pula banyak suruhan Nabi kepada ummatnya untuk melakukan perkawinan. Diantarnya tersebut dalam hadits nabi dari anas bin Malik menurut riwayat Ahmad dan disahkan oleh Ibnu Hibban sebagai berikut :

"Artinya : kawinilah perempuanperempuan yang dicintai yang subur karena sesungguhnya aku akan bangga karena banyak kaum di hari kiamat".

Atas dasar ini hukum perkawinan menurut asalnya adalah sunnah menurut pandangan jumhur ulama', hal ini berlaku secara umum. Namun karena ada tujuan mulia yang hendak dicapai dari perkawinan itu dan yang melakukan perkawinan itu berbeda pula kodisinya serta situasi yang melingkupi suasana perkawinan itu berbeda pula. Maka secara rinci jumhur ulama' menyatakan hukum perkawinan dengan melihat keadaan orang-orang tertentu sebagai berikut :

1. Sunnah, bagi orang-orang yang telah berkeinginan untuk kawin, telah pantas untuk kawin dan dia telah mempunyai perlengkapan untuk melangsungkan perkawinan.

2. Makruh bagi orang-orang yang belum pantas untuk kawin, belum berkeinginan untuk kawin, sedangkan perbekalan untuk perkawinan juga belum ada. Begitu pula ia telah mempunyai perlengkapan untuk perkawinan, namun fisiknya mengalami cacat seperti impoten, 
berpenyakitan tetap, tua dan kekurangan fisik lainnya.

3. Wajib, bagi orang-orang yang telah pantas untuk kawin, berkeinginan untuk kawin dan memiliki perlengkapan untuk kawin, ia khawatir akan terjerumus ke tempat maksiat kalau ia tidak kawin.

4. Haram, bagi orang yang tidak akan memenuhi ketentuan syara' untuk melakukan perkawinan atau ia yakin perkawinan itu tidak akan mencapai tujuan syara', sedangkan dia meyakini perkawinan itu akan merusak kehidupan pasangannya.

5. Mubah bagi orang-orang yang pada dasarnya belum ada dorongan untuk kawin dan perkawinan itu tidak akan mendatangkan kemudaratan apa-apa kepada siapapun. ${ }^{12}$

\section{Pengertian Keluarga Sakinah,} Mawaddah dan Rahmah dalam AlQur'an

Menurut sejumlah pakar, sebagaimana dikutip oleh M. Quraish Shihab bahwa ada beberapa tahapan yang biasanya dilalui oleh pasangan suami isteri sebelum mencapai kehidupan keluarga sakinah yang dihiasi dengan mawaddah dan rahmah antara lain :

1. Tahap Bulan Madu. Pada tahap ini kedua pasangan benar-benar menikmati manisnya sebuah perkawinan. Mereka sangat romantis, penuh cinta dan senda gurau. Pada tahap ini biasanya digambarkan bahwa masing-masing bersedia melalui kehidupan ini walaupun dalam kemisknan dan kekurangan.

2. Tahap Gejolak. Pada tahap ini mulai timbul gejolak setelah berlalu masa bulan madu. Kejengkelan sudah mulai tumbuh dihati apalagi sudah mulai terlihat sifat-sifat aslinya yang bahwa selama ini disengaja ditutup-tutupi untuk menyenangkan pasangannya. Mereka mulai menyadari bahwa perkawinan ternyata bukan sekedar romantisme, tetapi ada kenyataankenyataan baru yang boleh jadi tidak pernah terpikirkan sebelumnya. Pada tahap ini sebuah perkawinan akan terancam gagal dan masing-masing pihak biasanya merasa menyesal karena ia memilih ia sebagai pasangan hidupnya . namun dengan kesabaran dan tolerensi akan menghantarkan pada tahap ketiga.

3. Tahap Perundingan dan Negosiasi. Tahap ini lahir jika masing-masing pihak masih merasa saling membutuhkan. Pada tahap ini mereka sudah mulai mengakui kelebihan dan kekurangan masing-masing. Jika mereka berhasil melewati tahap ini, 
maka akan membawa tahap berikutnya.

4. Tahap penyesuaian. Tahapa ini masingmasing pasangan sudah mulai menunjukkan sifat aslinya, sekaligus kebutuhan yang disertai perhatian kepada pasangannya. Dalam tahap ini masing-masing akan saling menunjukkan sikap penghargaan. Mereka juga merasakan kembali nikmatnya menyatu bersama kekasih serta berkorban dan mengalah demi cinta.

5. Tahap Peningkatan Kualitas Kasih Sayang. Pada tahap ini masing-masing pasangan sudah menyadari sepenuhnya yang didasarkan pada pengalaman bukan teori bahwa hubungan suami isteri memang sangat berbeda dengan segala bentuk hubungan social lainnya. Pada tahap ini masing-masing pihak menjadi teman terbaik dalam bercengkrama, berdiskusi serta berbagai pengalaman. Masing-masing pihak juga berusaha untuk melakukan yang terbaik demi menyenangkan pasangannya.

6. Tahap Kemantapan. Pada tahap ini masing-masing pasangan merasakan dan menghayati cinta kasih sebagai realitas yang menetap sehingga sehebat apapun guncangan yang mendera mereka tidak akan menggoyahkan rumah tangganya. Memang riak-riak kecil masih akan tetap ada namun itu akan menghanyutkan. Pada tahap ini mereka benar-benar merasakan cinta sejati.

Tahap-tahapan diatas merupakan gambaran umum yang biasa dialami dalam hubungan suami isteri. Hal ini juga bersifat relatif sehingga tidak bisa dikalkulasi secara matematis, misalnya pada tahun pertama, kedua dan seterusnya. Begitu pula urutan ini tidaklah berisifat permanen, tetapi merupakan hasil sebuah penelitian atau ijtihad. Oleh karenanya tidak menutup kemungkinan adanya tahap-tahap lain selain diuraikan diatas.

Dalam rangka upaya memahami konsep sakinah, mawaddah, warahmah, maka dalam kesempatan ini penulis akan mencoba sedikit memaparkan beberapa definisi tentang sakinah, mawaddah, warahmah. Namun sebelum membahas mengenai pengertian keluarga sakinah, mawaddah dan rahmah, maka dijelaskan terlebih dahulu yang dimaksud dengan keluarga. Keluarga adalah unit terkecil dalam masyarakat yang terdiri dari suami, isteri dan anaknya, atau ayah dan anaknya atau ibu dan anaknya. ${ }^{13}$ 
Definisi lainnya tentang keluarga yaitu "Sekumpulan orang yang diikat oleh tali perkawinan, hubungan darah dan pengangkatan anak dalam satu rumah tangga, yang berinteraksi dan berkomunikasi satu sama lain sesuai dengan peran masing-masing, seperti suami, isteri, ayah dan ibu, saudara atau anak laki-laki dan perempuan yang saling memelihara hubungan budaya yang sama".14 Berdasarkan definisi diatas, jelaslah bahwa keluarga adalah suatu unit atau sekumpulan orang yang terdiri ayah, ibu dan anak yang diikat dalam perkawinan, hubungan darah atau pengangkatan anak.

\section{a. Pengertian Sakinah}

Kata Sakinah berasal dari Bahasa Arab yang berarti "Ketenangan hati". ${ }^{15}$ Sedangkan dalam Kamus Umum Bahasa Indonesia, Sakinah berarti : "Damai, tempat yang aman dan damai". ${ }^{16}$ Sedangkan Mawaddah juga berasal dari Bahasa Arab dari kata wadda- yawaddumawaddatan yang berarti "Kasih Sayang"17 dan Rahmah juga berasal dari Bahasa Arab dari kata rahima-yarhamurahmah yang berarti "Mengasihi atau menaruh kasihan"18 "Belas kasihan atau mengasihi"19 Keluarga sakinah adalah keluarga yang hidup dalam keadaan tenang, tentram, seia sekata, seayun selangkah, ada sama dimakan dan kalau tidak ada sama dicari.

Kata sakinah ditemukan dalam AlQur'an sebanyak enam kali disamping bentuk lain yang seakar dengannya dan secara keseluruhannya berjumlah 69. Kata sakinah yang berasal dari kata sakanayaskunu pada mulanya berarti sesuatu yang tenang atau tetap setelah bergerak (Subutusy-Syai' ba'dat Taharruk). ${ }^{20}$ Kata ini merupakan antonim dari idtiraab (kegoncangan) dan tidak digunakan kecuali untuk menggambarkan ketenangan dan ketentraman setelah sebelumnya terjadi gejolak apapun latar belakangnya., rumah dikatakan maskan karena ia merupakan tempat untuk istirahat setelah berkativitas. Sebagaimana dijelaskan dalam surat saba' surat ke-34 ayat 15 dan surat at taubah surat ke- 9 ayat 2.

\section{b. Pengertian Mawaddah}

Keluarga mawaddahitu adalah keluarga yang hidup dalam suasana kasih mengasihi, saling membutuhkan, hormat menghormati antara satu dengan yang lain. Kata mawaddah ditemukan sebanyak 8 kali dalam Al-Qur'an . secara keseluruhan dengan kata-kata yang seakar dengannya, semua berjumlah 25 .

Kata mawaddah berasal dari wadda-yawadda yang berarti mencintai 
sesuatu dan berharap untuk bisa terwujud (mahabbatusy-syai'n watamanni kaunihi). ${ }^{21}$ Menurut Al-Asfahani kata mawaddah bisa dipahami dalam beberapa pengertian berikut ini : 22

1. Berarti cinta (mawaddah) sekaligus keinginan untuk memiliki (tamanni kaunihi). Antara kedua kata ini saling berkaitan yakni disebabkan adanya keinginan yang kuat akhirnya melahirkan cinta atau karena didorong rasa cinta yang kuat akhirnya meelahirkan keinginan untuk mewujudkan sesuatu yang dicintainya. Hal ini bisa dilihat pada firman Allah SWT dalam surat Ar-Rum surat ke 30 ayat 21. Mawaddah sebagai salah satu yang menghiasi perkawinan bukan sekedar cinta sebagaimana kecintaan orang tua kepada anak-anaknya. Sebab rasa cinta disini akan mendorong pemiliknya untuk mewujudkan cintanya sehingga menyatu. Inilah yang tergambar dalam hubungan lakilaki dan perempuan yang terjalin dalam sebuah perkawinan. Ketika seseorang laki-laki mencintai seorang perempuan, maka ia ingin sekali untuk mewujudkan cintanya dengan memiliki atau menikahinya. Begitu pula sebaliknya ketika seorang perempuan mencintai seorang laki-laki, maka ia sangat menginginkan terwujud cintanya itu dengan menjadi isterinya. Dari sinilah sementara ulama' ada yang mengartikan mawaddah dengan mujaama'ah (bersenggama). ${ }^{23}$

2. Berarti kasih sayang. Hal ini bisa dipahami dari fiman Allah SWT dalam Surat Asy-Syuura Surat ke-42 ayat 23 :

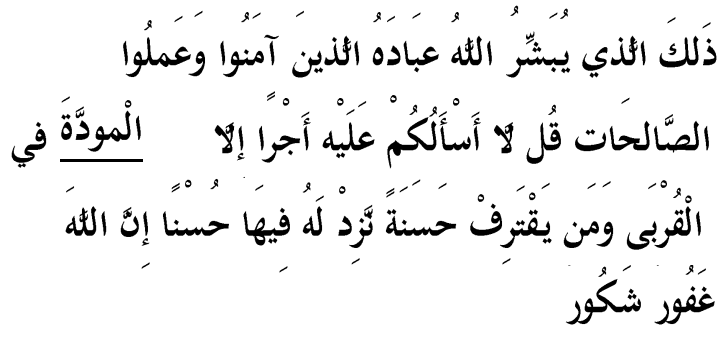

Artinya : Itulah (karunia) yang (dengan itu) Allah menggembirakan hamba-hambaNya yang beriman dan mengerjakan amal yang saleh. Katakanlah: "Aku tidak meminta kepadamu sesuatu upahpun atas seruanku kecuali kasih sayang dalam kekeluargaan". Dan siapa yang mengerjakan kebaikan akan Kami tambahkan baginya kebaikan pada kebaikannya itu. Sesungguhnya Allah Maha Pengampun lagi Maha Mensyukuri.

Kata mawaddah disini hanya sematamata mencintai dan menyayangi layaknya dalam hubungan kekerabatan, berbeda dengan cintanya suami dan isteri. Dalam hal ini bentuk cinta dan kasih sayang dengan senantiasa menjaga hubungan kekerabatan agar tidak terputus. ${ }^{24}$ Sebagaimana dalam riwayat At-Tabrani 
dari Ibnu Abbas yang dikutip oleh Ibnu

Katsir :

$$
\begin{aligned}
& \text { قا ل لهم ر سو ل الله صلى } 1 \text { الله عله و سلم : }
\end{aligned}
$$

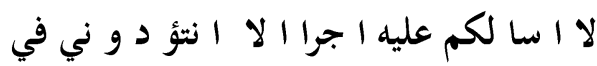

$$
\begin{aligned}
& \text { نفسي لقر ا بتي منكم تحفظو } 1 \text { القر ا بة بيني و } \\
& \text { بينكم (روا الطبر ا ني) }
\end{aligned}
$$

Artinya : Rasulullah SAW bersabda kepada mereka : aku tidak meminta upah kepada kalian kecuali agar kalian tetap menyayangiku karena adanya hubungan kekerabatandan agar kalian senantiasa memelihara hubungan kekerabatan antara aku dan kalian. (HR. Tabrani)

Sebagaimana Allah juga disifati dengan al-waduud yakni maha mencintai hamba yang mencintai-Nya. Dalam istilah lain cinta Allah diberikan kepada hamba-hamba-Nya yang beriman dan beramal shalih sebagai bukti kecintaan kepada-Nya. Allah berfirman dalam surat Maryam Surat ke-19 Ayat 96 :

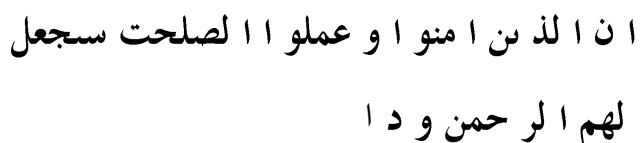

"Artinya : sungguh orang-orang yang beriman dan mengerjakan kebajikan, kelak Allah yang maha pengasih akan menanamkan rasa kasih sayang dalam hati mereka". 25

3. Berarti ingin, sebagaimana dalam beberapa firman Allah berikut ini :

$$
\text { و د ت طاؤفة من ا هل الكتب لو نضلو نكم }
$$

"Artinya : segolongan ahli kitab ingin menyesatkan kamu"26

Dalam Firman yang lain Allah menyampaikan :

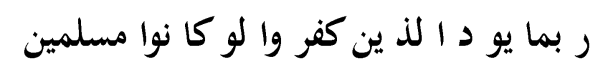

"Orang kafir itu kadang-kadang (nanti di akhirat) menginginkan, sekiranya mereka dahulu di dunia menjadi orang muslim. ${ }^{27}$

\section{c. Pengertian Rahmah}

Kata rahmah baik sendiri maupun dirangkai dengan kata ganti (dhamir) seperti rahmati dan rahmatuka, ditemukan di dalam Al-Qur'an sebanyak 114 kali. Secara keseluruhan dengan katakata lain yang seakar dengannya semuanya 339.28

Kata rahmah berasal dari rahimayarhamu yang berarti kasih sayang (riqqah) yakni sifat yang mendorong untuk berbuat kebajikan kepada siapa yang dikasihi. Menurut Al-Asfahaani, kata rahmah mengandung dua arti kasih sayang (riqqah) dan budi baik/murah hati (ihsan). ${ }^{29}$ Kata rahmah yang berarti kaih sayang adalah dianugerahkan oleh Allah SWT kepada setiap manusia. Artinya dengan rahmat Allah tersebut manusia akan mudah tersentuh hatinya jika melihat pihak lain yang lemah atau merasa iba atas penderitaan orang lain. Bahkan sebagai wujud kasih sayangnya seseorang berani berkorban dan bersabar untuk menanggung rasa sakit. Hal ini dapat dilihat pada kasus seorang ibu yang baru saja melahirkan, dimana secara demonstratif ia akan mencium bayinya pada hal sebelumnya ia berada dalam 


\section{Henderi Kusmidi \\ Kansep Sakinah, Mawaddah dan Rahmah dalam Pernikahan}

kondisi yang penuh kepayahan dan sakit yang teramat sangat.

Disamping pernyataan sifat kasih sayang yang teah ditancapkan pada diri manusia seharusnya menumbuhkan kesadaran bahwa segala bentuk kebaikan, kasih sayang, perhatian, juga budi baik bukanlah terlahir dari sifatnya sendiri, juga bukan karena kemurahan hatinya. Namun sebagai realisasi dari sebagian kecil rahmat Allah yang ditancapkan ke dalam lubuk hatinya. Sebagaimana yang bisa kita pahami pada hadits berikut :
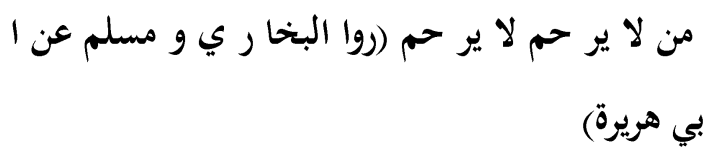

"Artinya : barangsiapa yang tidak mengasihi tidak akan dikasihi (HR. Bukhari dan Muslim dari Abu Hurairah"

Dalam hadts lain dijelaskan :

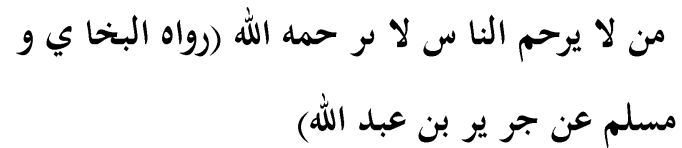

"Artinya: siapa yang tidak menyayangi orang lain, ia tidak akan disayangi Allah (HR. AlBukhari dan Muslim dari Jarir bin Abdullah).

Dari kedua hadits diatas dapat dipahami bahwa rasa belas kasih sayang yang ditancapkan dalam diri seseorang akan hilang jika ia tidak menyayangi kepada sesamanya secara tulus. Rasulullah SAW juga tidak mengakui orang yang tidak menyayangi kepada yang kecil sebagai bagian dari ummatnya. Sementara kata rahmah yang berarti ihsan (budi baik/murah hati) adalah khusus milik Allah SWT. Artinya hanyalah Allah yang boleh menyatakan atau mengklaim sebagai yang memiliki budi baik atau dengan kata lain kebaikan, perhatian, kasih sayang apapun bentuknya yang diberikan kepada seluruh makhluknya adalah karena kemurahan Allah, sehingga ia disifati sebagai Sang Maha Pemurah atau Ar-Rahman. Oleh karenanya sifat arrahman hanya boleh disandang oleh Allah semata, karena kata tersebut mengisyaratkan kesempurnaan..$^{30}$

Dengan sifat ini pula Allah tidak pernah mempetimbangkan ketaatan atau ketidaktaatan seseorang dalam memberi rezeki. Rahmat Allah juga ada yang terlahir sifat ar-rahim-Nya. Dalam hal ini al-Qur'an menyatakan bahwa curahan rahim-Nya hanya diberikan kepada hamba-Nya yang memenuhi kreteria, yang disitilahkan oleh Al-Qur'an dengan "Mukmin" (Al-Ahzab : 33 : 43), sehingga ada yang mengatkan bahwa Allah adalah "Ar-Rahman" di dunia dan "Ar-Rahim" ketika di akhirat. Dengan demikian karena kemurahan Allah dapat dinikmati oleh siapa saja baik mukmin maupun kafir, sedangkan di akhirat rahmat Allah hanya khusus bagi orang beriman. ${ }^{31}$

Penjelasan ini diperkuat oleh firman Allah SWT dalam surat Al-A'raf surat ke-7 ayat 156 berikut : 


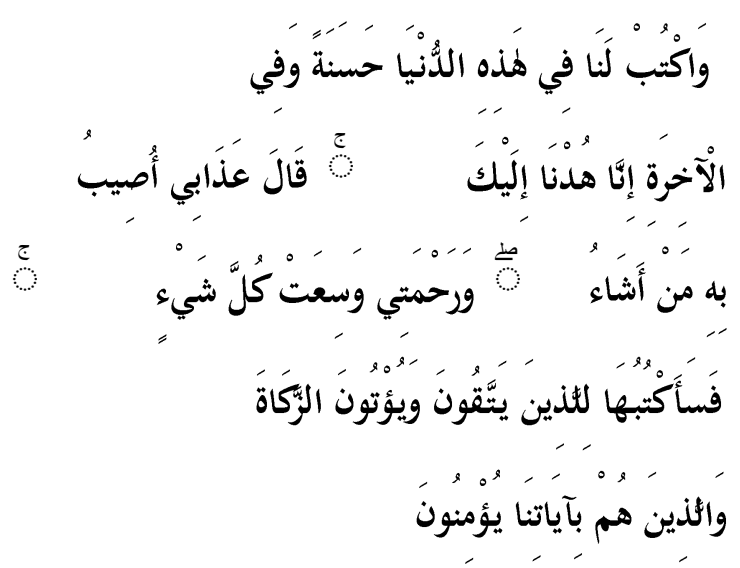

Artinya: Dan tetapkanlah untuk kami kebajikan di dunia ini dan di akhirat, sesungguhnya kembali (bertaubat) kepada Engkau. Allah berfirman : "siksaan-Ku akan Kutimpakan kepada siapa yang Aku kehendaki dan RahmatKu meliputi segala sesuatu. Maka akan Aku tetapkan Rahmat-Ku untuk orangorang yang bertaqwa, yang menunaikan zakat dan orang-orang beriman kepada ayat-ayat Kami".32

Keluarga rahmah adalah keluarga yang hubungan antar sesama anggota keluarga tersebut saling menyayangi, mencintai sehingga kehidupan keluarga tersebut diliputi oleh rasa kasih sayang. Walaupan ada 3 suku kata yang berbeda yaitu sakinah, mawaddah dan rahmah, namun ketiga kata tersebut bukan berarti harus diartikan secara terpisah dan sendiri-sendiri, akan tetapi justru ketiga suku kata tersebut menjadi satu yang dihubungkan dengan kata keluarga. Oleh karena itu, tidak perlu dibedakan mana keluarga sakinah, mana

keluarga yang mawaddah dan mana keluarga rahmah, tapi yang lebih tepat adalah sebuah keluarga sakinah, mawaddah dan rahmah.

Gabungan ketiga suku kata tersebut akan saling melengkapi dan memberikan kesempurnaan. Sehingga dapat diambil pemahaman bahwa yang dimaksud dengan

keluarga sakinah, mawaddah dan rahmah adalah : "Keluarga yang dibina atas perkawinan yang sah, mampu memenuhi hajat spiritual dan material secara layak dan seimbang, diliputi suasana kasih sayang antara anggota keluarga dan lingkungannya secara selaras, serasi serta mampu mengamalkan dan memperdalam nilai-nilai keimanan, ketakwaan dan akhlak mulia" 33

Pengertian lain tentang keluarga sakinah, mawaddah dan rahmah itu adalah : "Keluarga yang telah dapat memenuhi seluruh kebutuhan keimanan, ketakwaan dan akhlakul karimah secara sempurna, kebutuhan sosial psikologis dan perkembangannya serta dapat menjadi suri tauladan bagi lingkungannya"34 Untuk mencapai keluarga sakinah, mawaddah dan rahmah ini tidaklah terbentuk dengan otomatis apabila telah menikah saja, tetapi harus ada upaya yang serius dari kedua suami isteri, terutama harus dapat menempatkan posisi di situasi keluarga dan 
melaksanakan tugas dan kewajiban secara berimbang pula.

\section{Hak dan Kewajiban Suami Isteri}

\section{Dalam Perkawinan}

Berdasarkan kesimpulan hak-hak yang diwajibkan dalam Islam, bagi masing-masing suami isteri memiliki hakhak dan kewajiban antara satu dengan lainnya yang diklasifikasikan sebagai berikut : hak-hak suami dan kewajibankewajiban isteri, hak-hak isteri dan kewajiban-kewajiban suami serta hak-hak yang berhubungan antara suami isteri. ${ }^{35}$

\section{Hak-Hak Suami Isteri}

\section{a. Hak Suami Atas Isteri antara lain :}

1. Isteri hendaklah taat kepada suami dalam melaksanakan urusan rumah tangga selama suami menjalankan ketentuan-ketentuan Islam yang berhubungan dengan kehidupan suami isteri (lihat Al-Qur'an Surat An-Nisaa' ayat 34 )

2. Isteri mengurus dan menjaga rumah tangga termasuk mengasuh dan memelihara anak dan harta rumah tangga (lihat Al-Qur'an Surat An-Nisaa' ayat 34 )

\section{b. Hak Isteri atas Suami antara lain :}

1. Memperoleh mahar dan nafkah dari suami, yang dimaksud dengan nafkah disini adalah meliputi makanan dan minuman, pakaian, tempat tinggal, pengobatan dan lain-lain. Kalau suami tidak memberikan nafkah boleh isteri mengambil harta suami tanpa sepengetahuannya yang mencukupi baginya dan anaknya dengan cara yang baik.

2. Mendapat perlakuan yang baik dari suami (Surat An-Nisa' : 19)

3. Suami menjaga dan memelihara isterinya yaitu menjaga kehormatan isteri, tidak menyia-nyiakannya dan menjaga agar selalu melaksanakan perintah Allah.

c. Hak Bersama Suami Isteri antara lain :

1. Halalnya pergaulan suami isteri dan kesempatan saling menikmati atas dasar kerjasama dan saling memerlukan.

2. Perlakuan dan pergaulan yang baik.

3. Haram mushoharoh yaitu isteri haram dinikahi oleh ayah suaminya, dengan kata, anaknya dan cucunya juga ibu isteri, anak perempuannya dan seluruh cucunya haram dinikahi oleh suaminya

4. Saling mewarisi.

5. Sahnya menasabkan anak pada suami. ${ }^{36}$

\section{Kewajiban Suami Isteri Dalam}

\section{Perkawinan}

\section{a. Kewajiban Suami}

1. Suami berkewajiban memberikan nafkah kepada isteri dan anakanaknya, tetapi Islam tidak melarang 
isteri membantu suaminya dalam mencari nafkah dengan izin suaminya, sepanjang tidak mengganggu tugasnya sebagai isteri dan ibu rumah tangga.

2. Menuntun dan membimbing isteri serta anak-anaknya agar taat dan patuh menjalankan ajaran agamanya.

3. Bergaul dengan cara yang baik kepada isterinya yaitu menghormati dan memperlakukannya secara wajar, memperhatikan kebutuhannya, menahan diri dari sikap yang tidak menyenangkan dan tidak boleh berlaku kasar terhadap isterinya.

4. Menciptakan suasana kehidupan rumah tangga yang aman dan tenteram, rukun dan damai yang dijalin dengan kemesraan dan kasih sayang.

5. Membantu tugas-tugas isteri terutama dalam memelihara dan mendidik anakanaknya.

6. Memberikan kebebesan berpikir dan bertindak kepada isteri sesuai dengan ajaan agama, tidak mempersulit, apalagi sampai membuat isteri menderita lahir dan batin yang dapat mendorong isteri berbuat salah.

7. Dapat mengatasikeadaan dan kesulitan, mencari penyelesaian secara bijaksana dan tidak berbuat sewenangwenang.

\section{b. Kewajiban Bersama Suami Isteri}

1. Saling menghormati keluarga dan orang tua serta keluarga kedua belah pihak.

2. Memupuk rasa cinta dan kasih sayang. Masing-masing harus menyesuaikan diri seia sekata, saling mempercayai serta bermusyawarah untuk kepentingan bersama.

3. Hormat menghormati, sopan santun, penuh pengertian serta bergaul dengan baik

4. Matang dalam berbuat serta berpikir serta tidak bersikap emosional dalam memecahkan persoalan yang dihadapi.

5. Memelihara kepercayaan dan tidak saling membuka rahasia pribadi.

\section{E. Urgensi dan Konsekuensi Pernikahan}

Perkawinan merupakan ikatan lahir batin dan persatuan antara dua pribadi yang berasal dari keluarga, sifat, kebiasaan dan budaya yang berbeda. Perkawinan juga memerlukan penyesuaian secara terus menerus. Setiap perkawinan memerlukan cinta dan saling menerima pasangan masing-masing dengan latar belakang yang merupakan bagian dari kepribadiannya. Hal ini berarti mereka juga harus bersedia menerima dan memasuki lingkungan sosial budaya pasangannya dan karenanya diperlukan keterbukaan dan 
toleransi yang sangat tinggi serta saling penyesuaian diri yang harmonis. ${ }^{37}$

Ketika suami dan isteri berikrar untuk menikah berarti masing-masing mengikatkan diri pada pasangan hidup. Kebebasan sebagai individu dikorbankan, perkawinan bukan sebuah titik akhir, tetapi sebuah perjalanan panjang untuk mencapai tujuan yang disepakati berdua. Setiap pasangan harus terus belajar mengenai kehidupan bersama. Setiap pasangan juga harus kian menyiapkan mental untuk menerima kelebihan sekaligus kekurangan pasangannya dengan kontrol diri yang baik. 38

\section{F. Kesimpulan}

Dari beberapa paparan diatas penulis simpulkan bahwa perkawinan itu bukan sekedar pertemuan dua jenis kelamin untuk memperoleh keturunan, apalagi hanya sekedar untuk menyalurkan hasrat biologisnya. Namun harus ada tujuan yang lebih substantif dan bermakna yakni terciptanya keluarga sakinah yang diliputi oleh rasa kasih (mawaddah) dan sayang (rahmah). Manusia adalah makhluk yang memiliki kemampuan untuk berketurun sebagaimana makhluk hidup lainnya. Hanya saja dalam tataran prosesnya manusia berbeda dengan binatang. Ada aturan yang harus dipenuhi sebelumnya yakni melalui sebuah jenjang perkawinan yang sah menurut agama.

Melalui perkawinan yang sah itulah manusia akan memperoleh ketenangan dan ketenteraman, miskipun sebelumnya keduanya tidak saling mengenal pribadi masing-masing secara mendalam. Dari sinilah kemudian muncul saling menyayangi dan mengasihi,sehingga keduanya bisa memiliki keturunan.

Sakinah sebagai tujuan perkawinan tidak diungkapkan dengan kata benda (isim) akan tetapi dengan kata kerja (taskunu/yaskunu) yang menunjukkan arti huduus (kejadian baru) dan tajaddud (memperbaharui). Sakinah bukan sesuatu yang sudah jadi atau sekali jadi, namun harus diupayakan secara sungguh-sunguh (mujaahadah) dan terus menerus diperbaharui sebab ia bersifat dinamis yang senantiasa timbul tenggelam. Atau dengan kata lain sebuah perkawinan yang sakinah bukan berarti sebuah itu tidak pernah ada masalah karena perkawinan bagaikan bahtera yang mengarungi lautan dan setenang-tenangnya lautan pasti ada ombak. Gambaran sederhana dari keluarga sakinah adalah jika masingmasing pihak penuh dengan kesungguhan untuk mengatasi masalah yang timbul, dengan didasarkan pada keinginan yang 
kuat untuk menuju terpenuhinya ketenangan dan ketenteraman jiwa manusia.

\section{Referensi}

${ }^{1}$ Ali Yusuf As Subki, Figh Keluarga (Pedoman berkeluarga Dalam Islam), Penerbit AMZAH, Cetakan Pertama Tahun 2010 Jakarta, hal. 23

${ }^{2}$ Ali Yusuf As Subki, Figh Keluarga (Pedoman berkeluarga Dalam Islam), hal. 37

${ }^{3}$ QS. An-Nisa' Ayat : 21

${ }^{4}$ HR Ath-Thabrani di kitab Mu'jamul Ausath dan Syaikh Al Albani rahimahullah menghasankannya. Lihat Silsilah Al Ahadits Ash Shahihah, no. 625.

${ }^{5} \mathrm{HR}$ Abu Dawud, No. 2.050, An Nasa-i (VI/65-66), Al Hakim (II/162), Al Baihaqi (VII/81) dari Ma'qil bin Yasar dan dishahihkan oleh Syaikh Al Albani rahimahullah di dalam Irwaa-ul Ghaliil, No. 1.784

${ }^{6}$ Quraish Shihab, Keluarga Sakinah, Dalam Jurnal Bimas Islam, Volume 4 No. 1 Tahun 2011, hal. 4

7QS. Ar-Rum Surat ke-30 : 21

${ }^{8} \mathrm{QS}$. An-Nahl Ayat ke-72

${ }^{9}$ H.M.A. Tihami dan Sohari Sahrani, Figh Munakahat (Kajian Figh Nikah Lengkap), Penerbit PT. Raja Grafindo Persada Jakarta, 2009, hal. 8-10

10Amir Syarifuddin, Garis-Garis Besar Figh Edisi Pertama Cetakan Ke-3, Penerbit Prenada Media Group, Jakarta Tahun 2003, hal. 78-79

11QS. An-Nuur Ayat : 32

${ }^{12}$ Amir Syarifuddin, Garis-Garis Besar Figh Edisi Pertama Cetakan Ke-3, hal. 80

${ }^{13}$ Rizki Takriyanti, Konseling Keluarga

Sakinah, IAIN STS Jambi, 2009 hal. 3

${ }^{14}$ Rizki Takriyanti, Konseling Keluarga

Sakinah, IAIN STS Jambi, 2009 hal. 3

15Mahmud Yunus, 1972, Kamus Arab Indonesia, Jakarta : Mahmud Yunus Wadzurryah, hal. 174

16WJS. Poerwadarminta, 1985, Kamus Umum Bahasa Indonesia, Jakarta : Balai Pustaka, hal. 851

17Mahmud Yunus 1972, Kamus Arab Indonesia, Jakarta : $\quad$ Mahmud Yunus Wadzurryah,., hal. 495

18Mahmud Yunus, 1972, Kamus Arab Indonesia, Jakarta : Mahmud Yunus Wadzurryah hal. 139
${ }^{19}$ WJS. Poerwadarminta, 1985, Kamus Umum Bahasa Indonesia, Jakarta : Balai Pustaka, hlm. 791

${ }^{20} \mathrm{Al}$ asfahani, al-mufradaat fi gharibil-Qur'an ditahqiq oleh Muhammad Sayyid al-Kailani, Daarul Ma'arifah, Beirut, tanpa tahun, pada term Sakana, hal. 236

${ }^{21}$ Lajnah Pentashihan Mushaf Al-Qur'an Badan Litbang dan Diklat Kementerian Agama RI, Tafsir Al-Qur'an Tematik Jilid 2, Penerbit Kamil Pustaka, Cetakan Pertama, Jakarta, 2014, hal. 39

${ }^{22}$ Al-Asfahani, Al-Mufradat pada term wadada, hal. 516

${ }^{23}$ Ar-Razi, Mafaatih al-Ghaib Jilid XXV, (t.t : t.p.t.th) , hal. 97

24Muhammad Ali Ash-Shabuni, Mukhtasar Tafsir Ibnu Katsir, Penerbit Daarur Rasyad, Mesir Tanpa Tahun Jilid III, hal. 275

${ }^{25}$ QS. Maryam Surat ke-19 Ayat : 96

${ }^{26}$ QS. Ali Imran Surat ke-3 Ayat : 69

${ }^{27}$ QS. Al-Hijr Surat ke-15 Ayat : 2

28Lajnah Pentashihan Mushaf Al-Qur'an Badan Litbang dan Diklat Kementerian Agama RI, Tafsir Al-Qur'an Tematik Jilid 2, hal. 41

${ }^{29}$ Al-Asfahani, Al-Mufradat pada term rahima, hal. 191

30Penambahan alif dan nun menunjukkan kesempurnaan (Lihat Az-Zarkasyi, Al-Burhan fi 'uluumil Qur'an)

31 Al-Asfahani, al-mufradat, hal. 192

32Departemen Agama RI, Al-Qur'an dan Terjemahannya, Penerbit Jumaanatul Ali Art, 2004, hal. 170

33Anonim, 2006, Modul Pelatihan Motivator Keluarga Sakinah, Jakarta : Dirjen Bimas Islam Direktorat Urusan Agama Islam dan Pembinaan Syariah Depag RI, hal. 31-32

${ }^{34}$ Rizki Takriyanti, Konseling Keluarga Sakinah, IAIN STS Jambi, 2009, hal. 7

${ }^{35}$ Ali Yusuf As-Subki, Figh Keluarga (Pedoman Bekeluarga Dalam Islam), hal. 143

${ }^{36}$ Huzaimah Tahido Yanggo, Masail Fiqhiyah (Kajian Hukum Islam Kotemporer) Cetakan Pertama, Penerbit Angkasa Bandung, 2005, hal. 136

37Sirajudin M, Zubaedi, Zulkarnain, Peranan BP.4 Dalam Memberikan Kesehatan Perkawinan Pada Masyarakat Modern Cetakan 1, Penerbit Teras Yogyakarta, 2010, hal. 15

38Sirajudin M, Zubaedi, Zulkarnain, Peranan BP.4 Dalam Memberikan Kesehatan Perkawinan Pada Masyarakat Modern Cetakan 1, hal. 16 